\title{
FEJÉRDY TAMÁS EMLÉKBESZÉDE*
}

Nagy veszteség érte a magyar müemlékvédelmet Winkler Gábor Ybl Miklós-díjas építész, az MTA doktora, egyetemi tanár hirtelen és váratlan eltávozásával.

E megrendítő hír vételekor még nem mérhető fel, mégis és máris: mindannyian szomorúan tudjuk és fájdalmasan érezzük, hogy kiemelkedő tudása és mélységes emberségével magával ragadó személyisége mennyire fog hiányozni a határainkon innen és túli mủemlékvédelemben! Winkler Gábornak a múemlékvédelemmel foglalkozók köreiben éppúgy, mint az építészeti kutatással, oktatással foglakozók, vagy éppen a hazai főépítészek között mindenki által ismert, elismert és szeretett személye, sokoldalú tevékenysége ezer szállal kötődött a magyar müemlékvédelem, a magyarországi épített kulturális örökség értékeinek felkutatásához, megőrzéséhez, ismertté és elismertté tételéhez.

Építészmérnök diplomájának megszerzése óta szinte azonnal és egyre elmélyültebb formában vette ki részét az építészeti oktatásból. Eleinte a Budapesti Műszaki Egyetem, majd a győri Széchenyi István Műszaki Főiskola keretei között, 1994-től a Soproni Egyetem Építéstani Tanszékének tanára, majd 1995-től a NyugatMagyarországi Egyetem, 2006-2011 között a Széchenyi István Egyetem egyetemi tanára; amelyekkel párhuzamosan részt vett határon túli (Kolozsvár, Pozsony, Graz) oktatási programokban is. A müszaki tudományok kandidátusa 1994 óta; PhD építészmérnöki tudományok 2004-töl; az MTA doktora 2004 óta.

Alkotó építészként új épületek, beépítési tervek, illetve számos sikeres müemlékhelyreállítás tervezője, építészettörténeti kutatóként - elsősorban, de nem kizárólagosan - Sopron város építészettörténeti kutatásában alkotott kiemelkedőt. Szerteágazó kutatói tevékenységének fontos állomása volt az „Elmúlt száz év történeti épületeinek" tematikus kutatása, amely nagymértékben járult hozzá a 19. századtól a 20. század közepéig keletkezett épített-örökségi értékek módszeres feltárásához, oroszlánrészt vállalva az épített örökségünkben számarányánál fogva is meghatározó jelentőségű időszak újraértékelésben is. Értékes publikációi közül is kiemelkedik

\footnotetext{
* Dr. Fejérdy Tamás DLA, okl. építészmérnök, okl. műemlékvédelmi szakmérnök, c. egyetemi docens, az ICOMOS Magyar Nemzeti Bizottság elnöke. A beszéd elhangzott 2015. május 29-én Győrben, a temetés alkalmával.
} 
a Győr várostörténeti dokumentumait (elsősorban a képi ábrázolások értékelő bemutatását) egybegyüjtő kétkötetes (Győr 1539-1939 és Győr 1939-1999) forrásgyüjtemény. Pápa városának fóépítészeként évtizedek (1974) óta példamutató és reményt keltően eredményes módon igazolta a gyakorlatban az elméleti munkáiban lefektetett elvek megvalósíthatóságát, bebizonyítva, hogy időtálló és elfogadott szakmai eredményeket az összes érintettel és érdekelttel való szoros párbeszédben és együttmüködésben lehet elérni.

Winkler Gábor - a fentiekben korántsem a maga teljességében felvázolt, és sajnos immár véglegesen lezárult - sokoldalú, egyszerre-párhuzamosan végzett tevékenységei mellett jelentős részt vállalt a müemlékvédelem nemzetközi szakmai civil szervezetének, az ICOMOS-nak a munkájában, évtizedeken keresztül annak egyik legaktívabb tagjaként, illetve különböző vezetői pozícióiban - egyebek közt a Magyar Nemzeti Bizottság elnökeként. Az oktatási és kutatási területen kivívott nemzetközi ismertségét és elismertségét ezen keresztül is a magyarországi eredmények propagálására használta fel.

Szakmai-társadalmi tevékenységei közül ki kell emelni az MTA Építészettörténeti és Elméleti munkabizottsága elnökeként végzett munkáját, valamint az Europa Nostra nemzetközi-európai együttmüködésben kifejtett széles körü, áldozatos tevékenységét. Az a tény, hogy Magyarország az egyik legtöbb Európa Nostra díjat elnyert ország, nem utolsó sorban éppen Winkler Gábor szakmai és szervezési tevékenységének köszönhető. Winkler Gábor a Hungaria Nostra (az Europa Nostra magyar tagszervezete = A Város- és Faluvédő Szervezetek Országos Szövetsége) alelnökeként országon belül hasonlóan magas színvonalú, sokoldalú és sikeres, a nemzetközi szervezetben nagyra értékelt és elismert munkát végzett a hazai örökség megőrzésének társadalmasítása érdekében. Talán kevésbé ismert, de nem kevésbé fontos az „Alpok-Adria Munkaközösség” határokon átívelő, regionális szakmai munkájában a kezdetektől vállalt és végzett, meghatározó jelentőségü részvétele.

Winkler Gábor elévülhetetlen érdemei közé tartozik a fiataloknak - tanítványainak és másoknak, a következő generációknak - a tudatos bevezetése a müemléki, értékvédelmi szemléletbe és munkába. Hihetetlen szorgalommal, munkabírással megszerzett tudását önzetlenül megosztva velük, egyszerre munkálkodott a múlt és a jövő érdekében, példát mutatva másoknak, és tudást, eszközt adva nekik. Winkler Gábor életművének elismerésével nemcsak eddigi munkásságának eredményeit, de kiemelkedő, példamutató személyiségét is fel lehet mutatni az ország közösségének. Valamennyiünk nagy büszkeségére és örömére nemrég, 2015. május 4-én vehette át az Akadémiai Díjat, ,,az építészettörténet, az urbanisztika, a műemlékvédelem és az építészeti tervezés területén kifejtett sikeres és eredményes szakmai, oktatói és kutatói tevékenységéért, a 19. század építészetének kutatása területén végzett iskolateremtő munkásságáért és nemzetközileg is elismert életmüvéért".

Fájdalommal búcsúzunk Winkler Gábortól, aki kiemelkedő, sokoldalú tudásával és fáradhatatlan szorgalmával egész életében a magyar müemléki értékek megőrzése 
érdekében munkálkodott, példájával oktatva és magával ragadva kollégáit, munkatársait és tanítványait. Távozása betölthetetlen ürt hagy maga után, még akkor is, ha tudjuk, hogy szelleme a müveiben és alkotásaiban közöttünk marad. Emlékét úgy őrizhetjük meg a legjobban, ha legjobb tudásunk szerint követjük a példáját, még akkor is, ha azt érezzük, hogy az Öáltala oly magasra tett mérce számunkra elérhetetlennek tünik. Nyugodjék békében! 